\title{
Artificial Seeds (Principle, Aspects and Applications)
}

\author{
Hail Z. Rihan ${ }^{1, *}$, Fakhriya Kareem ${ }^{1}$, Mohammed E. El-Mahrouk ${ }^{2}$ and Michael P. Fuller ${ }^{1}$ \\ 1 School of Biological and Marine Sciences, Faculty of Science and Engineering, Plymouth University, \\ Plymouth PL4 8AA, UK; fakhriya.kareem@plymouth.ac.uk (F.K.); mfuller@plymouth.ac.uk (M.P.F.) \\ 2 Department of Horticulture, Faculty of Agriculture, Kafrelsheikh University, Kafr El-Sheikh 33516, Egypt; \\ threemelmahrouk@yahoo.com \\ * Correspondence: hail.rihan@plymouth.ac.uk
}

Received: 20 September 2017; Accepted: 27 October 2017; Published: 3 November 2017

\begin{abstract}
Artificial seeds are artificially encapsulated somatic embryos (usually) or other vegetative parts such as shoot buds, cell aggregates, auxiliary buds, or any other micropropagules which can be sown as a seed and converted into a plant under in vitro or in vivo conditions. An improved artificial seed production technique is considered a valuable alternate technology of propagation in many commercially important crops and a significant method for mass propagation of elite plant genotypes. The production of plant clones multiplied by tissue culture and distributed as artificial seeds could be a useful alternative to the costly F1 hybrids for different plant crops. The delivery of artificial seeds also facilitates issues such as undertaking several ways for scaling up in vitro cultures and acclimatization to ex vitro conditions. The development of an artificial seed technique also provides a great approach for the improvement of various plant species such as trees and crops.
\end{abstract}

Keywords: synseed; sodium alginate; encapsulation; micropropagules and micropropagation

\section{Artificial Seeds Introduction and Definition}

The demand for artificial seed technology started after the discovery of somatic embryo production in various plant species in vitro. Artificial seeds, which are also known by other names such as "synseeds", are firstly described by Murashige [1]. He defined artificial seeds as "an encapsulated single somatic embryo". An artificial seed was later defined by Gray et al. [2] as "a somatic embryo that is engineered for the practical use in commercial plant production". The concept of artificial seeds was then limited to those plant species in which the production of their somatic embryos could be demonstrated.

The definition of artificial seeds depends on the similarity in physiology, morphology, and biochemistry of somatic embryos to zygotic embryos [3,4]. Considering the recalcitrance to somatic embryogenesis in some plant species, the concept of artificial seeds was later extended to be the encapsulation of a range of in vitro-derived propagules [5]. The definition of artificial seeds was then extended to be artificially coated somatic embryos (usually) or other vegetative parts such as shoot buds, cell aggregates, auxiliary buds, or any other micropropagules, provided that they have the capacity to be sown as a seed and converted into a plant under in vitro or ex vitro conditions. They should also be able to keep this ability for an extended period (storage ability) [6-8]. Therefore, artificial seeds can eliminate the acclimation steps necessary in micropropagation and give breeders greater flexibility [9]. Various plant materials have since been used for artificial seed production including somatic embryos, shoot tips, auxillary buds, nodal segmants, protocorm-like bodies (PLBs), microshoots, and embryogenic calluses [6,10-14]. Several studies have investigated the production of artificial seeds working with different plant species, including vegetables, fruits, medical plants, ornamentals, forest trees, orchids, and cereals [5,13,15-30], as cited in [29]. 
Although the vast majority of artificial seeds are produced from encapsulated in vitro-derived propagules, the possibility of encapsulating in vivo-derived propagules have been confirmed in some plant species [31]. For example, the success of encapsulation of dormant vegetative buds of an in vivo-cultured mature mulberry tree has been reported by Pattnaik et al. [32]. Furthermore, the production of artificial seeds from encapsulated Curcuma amada microshoots has been reported by Banerjee et al. [33], as cited from [31].

\section{The Importance, Uses and Advantages of Artificial Seeds}

By using the benefits of a vegetative regeneration system with the capability of long-term storage, different applications of artificial seeds in agriculture have been made [2,6]. Crops which are used for artificial seed production can be classified into two categories:

- Those that have a high quality of somatic embryos, and

- Those with a strong commercial basis [34].

Zygotic embryos are formed from the sexual recombination of male and female gametes. Thus, cuttings or other vegetative means are used for propagation and these methods rarely present convenient storage. Artificial seeds could be a good tool to propagate these types of plants and to store their propagules for a reasonable period of time [11]. Artificial seed production is an essential technique for the proliferation of plant species which are not able to produce seed, such as seedless grapes and seedless watermelon $[8,35]$. Artificial seeds can be employed for production of polyploids with elite traits, avoiding the genetic recombination when these plants are propagated using conventional plant breeding systems, thus saving on time and costs (Figure 1). Artificial seeds can be also used in the proliferation of male or female sterile plants for hybrid seed production [8]. Artificial seed production through the use of somatic embryos is an important technique for transgenic plants, where a single gene can be placed in a somatic cell and then this gene will be located in all the plants produced from this cell. Therefore, artificial seeds could be an efficient technology used for reproduction of transgenic plants [7].

The encapsulation technology can be considered as a promising approach that can be used for the exchange of plant materials between public and private plant tissue culture laboratories, and also to achieve germplasm conservation and the propagules that are derived from in vitro or by micropropagation applied directly in nurseries or in a field [36]. Moreover, artificial seeds, which are produced using tissue culture techniques that are aseptic, are free of pathogens, giving great advantages to these materials for transport across frontiers and for avoiding the spread of plant diseases [7,37]. Artificial seeds are also valuable in terms of their role in providing protective coating, increasing the level of micropropagule success in the field. These micropropagules need a protective coating to increase successful establishment in the field situation because of the sensitivity of uncovered micropropagules to drought and pathogens under natural environmental conditions [6]. Furthermore, artificial seeds are more durable for handling, transportation, and storage. Artificial seed production is also a useful technique as a clonal propagation system in terms of preservation of the genetic uniformity of plants, straight delivery to the field, low cost, and fast reproduction of plants (Figure 1).

Artificial seed production may offer a tool suitable for the extensive scale-up required for multi-clone commercial production [38]. Moreover, the use of this technique economizes upon the space, medium, and time requested by the traditional tissue culture methods [16]. Artificial seed production has great advantages in comparison with traditional tissue culture methods. Artificial seeds are reasonably inexpensive to produce and easy to handle, plant, and transport. They can also be stored for a long period using dehydration and cryopreservation techniques $[39,40]$.

Artificial seeds can be very useful for grass species as well as many others. Artificial seeds (encapsulated somatic embryos, in specific) can open new vistas for land restoration and the rehabilitation of wild lands (rangelands, grasslands, forests, abandoned mine lands, etc.) affected by 
overgrazing or climate change. Unfortunately, because of the abovementioned problems, the seed bank in the soil and the natural seed production of the mother plants cannot recover the loss of naturally reserved seeds year after year of pressure. Therefore, mass production of embryos or embryogenic calluses and their use for artificial seed production are important for the future of land restoration. However, there is a limited number of studies and literature that investigate the potential use of artificial seeds for land restoration, and this could be an important point for future research [1]. The use of tissue culture and micropropagation techniques with several plant species were summarized by [2]. However, more investigations are required to find out the possibility to develop the micropropagation systems to produce artificial seeds.

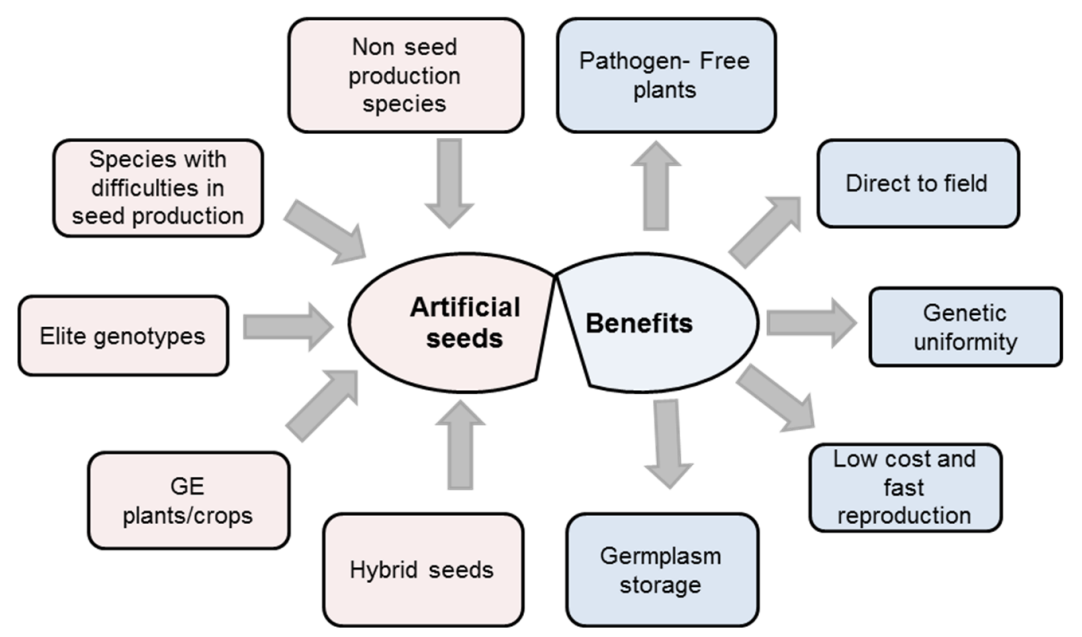

Figure 1. Artificial seed uses and benefits (modified from [41]).

\section{Artificial Seed Concept}

The artificial seed structure mimics that of the conventional seed. It consists of both explant material, which imitates the zygotic embryo in the conventional seed, and the capsule (gel agent and additional materials such as: nutrients, growth regulators, anti-pathogens, bio-controllers, and bio fertilizers), which emulates the endosperm in the conventional seed [35] (Figure 2).

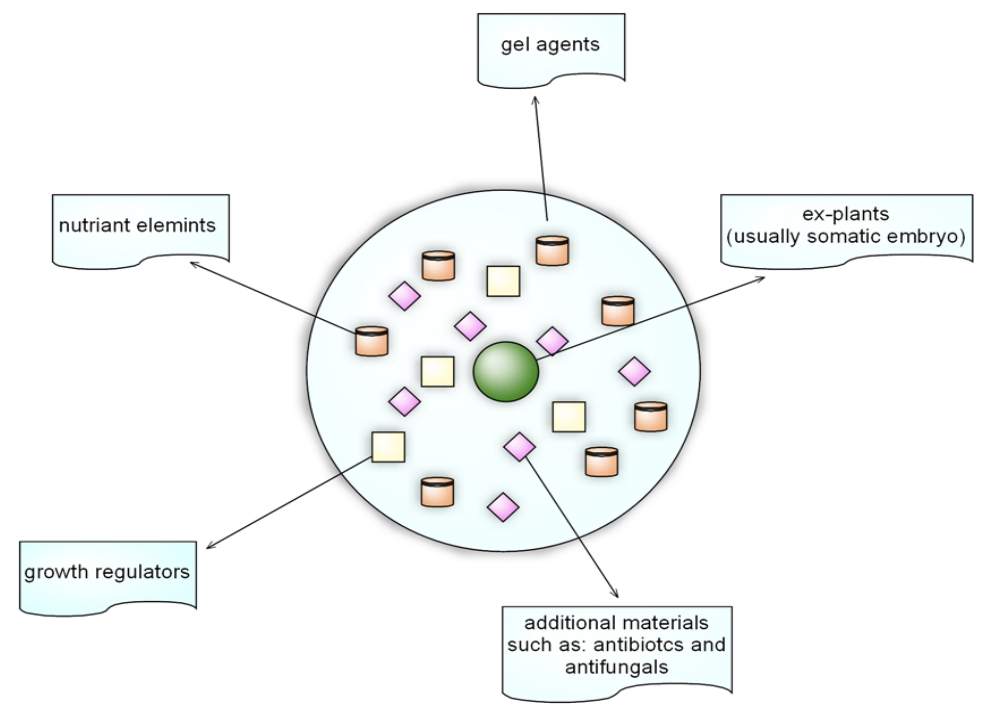

Figure 2. Artificial seed concept. 


\section{Essential Requirements for the Production of Artificial Seeds}

\subsection{Explant Material}

Explant materials are the basic generative component of the artificial seed. It could be:

\subsection{Somatic Embryos}

Somatic embryos are the most common micropropagule used for artificial seed production because their structures are able to produce the radical and plumule axis, which has the capability to progress into the root and shoot in a single step [6]. Artificial seeds produced through somatic embryos can also provide high levels of reproduction. Plant lines, which are produced via somatic embryos, are capable of keeping their regenerative capacity for a long time, resulting in uniform plant production [42], because it avoids the dedifferentiation callus stage, and consistent genetic structure production [43].

The use of somatic embryos for artificial seed production has become widespread over time, and the number of species which seem to have propagation ability using this technique is increasing. The production of artificial seeds via somatic embryos have been investigated in several plant species including carrot (Daucus carota) [44], alfalfa (Medicago sativa), Norway spruce (Picea abies) [45], sandalwood [45], pistachio (Pistacia vera) [46], sandalwood (Solanium album) [47], grape (Vitis vinifers) and mango (Mangifera indica L.) [48], citrus reticulata [49], Hopea parvitflora [50], Paulownia elongata [51], sugarcane [52], Oryza sativa (hybrid rice) [53], Rotula aquatic (takad) [54], Daucus carota (Latif et al., 2007), Pinus radiata [55], Nothofagus alpina [35], Catharanthus roseus (L.) G. Don [56], and many others (Table 1).

However, while Attree et al. [57] indicated that the somatic embryos of white spruce (Picea glauca) survived desiccation and grew to plantlets more strongly than its removed zygotic embryos cultured in vitro, Lulsdorf et al. [58] mentioned that the germination level of encapsulated white spruce (Picea glauca) and black spruce (Picea mariana) had reduced frequency in comparison with the correspondent zygotic embryos. Cartes et al. [35] reported that the encapsulated somatic and zygotic Rauli-Beech (Nothofagus alpine) embryos had the same germination habits, which depended on the type of encapsulation applied, and they mentioned that the germination level of zygotic embryos was higher in comparison to somatic embryos. An automatic production and encapsulation artificial seeds protocol was established by [9]. These authors mentioned that the optimal sowing state such as in a nursery bed in the field or in the greenhouse provides a high and homogeneous conversion of artificial seeds. They demonstrated that the conversion level of celery and carrot embryos can be raised from $0 \%$ to $53-80 \%$ by applying three essential treatments: (1) Culturing the embryos in medium culture with high osmolarity for 7 days: the embryo size was increased from 1-3 $\mathrm{mm}$ to $8 \mathrm{~mm}$, and the chlorophyll was also increased during this treatment; (2) the embryos water content was reduced from 95-99\% to 80-90\%; and (3) post-dehydration culture on SH medium, containing $0.01 \mathrm{mg} \cdot \mathrm{L}^{-1}$ $\mathrm{GA}_{3}, 0.01 \mathrm{mg} \cdot \mathrm{L}^{-1} \mathrm{BAP}$, and $2 \%$ sorbitol. The bead quality was also modified by adding $3 \%$ sucrose and a mixture of fungicides. It is believed that treating the embryos with high osmolarity at the entail culture stage helps to reduce the water content of the embryos. Moreover, this helps the embryos to acclimate to the new encapsulation conditions.

Ganapathi et al. [59] reported a conversion rate of $66 \%$ of $M u s a$ spp. artificial seeds produced by the encapsulation of their somatic embryos. Artificial seeds of Paulownia elongata were produced by the encapsulation of somatic embryos with a conversion rate that was assessed to be 50.3\% [51]. A $26 \%$ conversion rate was obtained by culture-encapsulated somatic embryos of Quercus robur in $\mathrm{P}_{24}$ medium supplemented with $0.1 \mu \mathrm{M}$ IBA, $0.9 \mu \mathrm{M}$ BA, and 3\% sucrose [51]. Kumar et al. [53] reported a $47 \%$ conversion rate of Oryza sativa cultured in Whatman filter paper. A 100\% conversion rate of Rotula aquatic artificial seeds produced by the encapsulation of its somatic embryos was achieved when the artificial seeds were cultured in MS medium [54]. Malabadi and Staden [60] and Manjkhola et al. [61] reported conversion rates of $89 \%$ and $60.6 \%$ of encapsulated somatic embryos of Pinus patula and Arnebia euchroma, respectively. The encapsulated somatic embryos of Acca sellowiana had a high conversion rate that was about $80 \%$ after 1.5 -years storage [62]. The cultivation of 
encapsulated somatic embryos of Psidium guajava in MS medium supplemented with 3\% sucrose showed a high conversion rate assessed to be $91.6 \%$ [13].

On the other hand, some authors consider that the degree of vigour or maturity of the embryos at the moment of being encapsulated can influence the germination of encapsulated somatic embryos (ESEs) [63,64], cited in [35]. It was also suggested that encapsulation can affect embryo respiration (Redenbaugh, 1990) and this in turn might influence the germination and viability of somatic embryos [65]. However, low germination and conversion rates were reported with different woody species mainly due to deficiencies and asynchronous maturation of the embryonic pole, which led to difficulties in the final stages of the process $[66,67]$ cited in [35].

Two types of artificial seeds (encapsulated somatic embryos) are commonly produced: desiccated and hydrated $[6,68]$.

1. Desiccated artificial seeds

Desiccated artificial seeds are achieved from somatic embryos either naked or encapsulated in polyoxyethylene glycol followed by their desiccation. Desiccation can be applied either rapidly by leaving artificial seeds in unsealed petri dishes on the bench overnight to dry, or slowly over a more controlled period of reducing relative humidity [6]. These types of artificial seeds can be only made in plants whose somatic embryos are desiccation-tolerant [31].

The desiccation tolerance of somatic embryos can be induced using a high osmotic potential of the maturation medium. The osmotic potential could be increased by using a high gel strength or by the addition of permeating osmoticants such as mannitol, sucrose, etc. [69]. Desiccation can also be induced by applying sub-lethal stresses such as nutrient deprivation or low temperature, since these treatments have been reported to have similar effects on desiccation tolerance [70].

2. Hydrated artificial seeds

Hydrated artificial seeds can be produced by encapsulating somatic embryos in hydrogel capsules. They are produced in plant species which are recalcitrant and sensitive to desiccation [6]. Encapsulation has been expected to be the best method to supply protection and to convert the in vitro micropropagules into 'artificial seeds' or 'synseeds' [71], and it is an important application of micropropagation to develop the success of in vitro-derived plant delivery to the field. However, somatic embryos need to be encapsulated in a suitable material that promotes germination [72].

- Apical shoot tips and axillary shoot buds and microshoots

Although unipolar axillary shoot buds and apical shoot tips contain no root meristem, they have been encapsulated to produce artificial seeds in several plant species. However, although these explants required some special treatment for induction of the reformation of roots before the encapsulation stage, some studies reported the conversion of encapsulated buds of banana [17] and mulberry [73] into plantlets without specific induction treatment. Ganapathi et al. [17] mentioned that $100 \%$ conversion of encapsulated banana shoot tips into plantlets was obtained using White's culture medium, and these plantlets were effectively based in soil. Piccioni and Standardi [74] reported that encapsulated micropropagated buds of six woody species—apple (Malus spp.), blackberry (Rubus spp.), birch (Betula pendula), kiwifruit (Actinidia deliciosa), raspberry (Rubus idaeus L.), and hawthorn (Crataegus oxyacantha) - were successfully regrown after encapsulation and cultivation on enriched media. Working in M.26 apple rootstock, encapsulated apical buds (artificial seed) showed higher levels of conversion in comparison with artificial seeds from axillary buds (the maximum conversion rates for encapsulated apical and axillary buds were $85 \%$ and $25 \%$, respectively) [75]. Lata et al. [38] mentioned that $100 \%$ conversion of encapsulated axillary buds was produced in the suitable capsulation matrix and the plantlets produced were effectively passed to the soil. These consequences prove the ability of such explants for encapsulation and artificial seed production. The encapsulation of cauliflower microshoots for artificial seed production was successfully achieved and the capacity to convert in commercial substrates was confirmed as well $[11,76]$. 
- Other explant materials

Several other explant materials, such as embryogenic masses and protocrom-like bodies, have been investigated to test their ability to produce artificial seeds, although the supporting of embryogenic masses in culture tubs is expensive and labour-intensive, and mechanically provoked bio-reactors require regular transfer of tissue to new media. Nonetheless, Onay et al. [46] were able to successfully produce artificial seeds via an embryogenic mass. They reported that the encapsulated embryogenic mass fractions regained their primary reproductive ability after two-month storage. The production of artificial seeds through encapsulated protocrom-like bodies of orchid (Geodorum densiflorium) was investigated by [77]. These authors mentioned that the encapsulated protocrom-like bodies retained their viability after three-month storage at $4{ }^{\circ} \mathrm{C}$, while non-encapsulated protocrom-like bodies appeared non-viable after one-month storage at $4{ }^{\circ} \mathrm{C}$. However, there is a variety of explants that could be used for artificial seed production, and this depends essentially on the plant species.

\section{Artificial Seed Gelling Agents and Adjuvant Materials}

The basic limitation for using somatic embryos as micropropagules for plant propagation is that the somatic embryos are delicate structures without a quiescent resting stage. Therefore, they require essential supplementary tissues that should provide the nutrient elements and a protective layer, which makes them easier to handle and store. Thus, the main objective of artificial seed research is the production of an artificial seed structure that stimulates the conventional seed in its characteristics (such as handling, storage, viability, and germination level) [6].

At the beginning of artificial seed studies, polyoxyethylene was selected as a suitable capsulation material to encapsulate celery embryos due to their positive properties, such as sustained embryo growth, non-toxicity to explants, and solubility in water [44]. Later applied to alfalfa embryos, Redenbaugh et al. [78] reported a new technology using hydrogel encapsulation. Since then, the hydrogel materials have been the main structure for somatic embryo encapsulation.

However, although many gel materials such as agar, alginate, carrageenan, guar gum, and sodium pectrate were investigated for artificial seed production, alginate matrix was discovered to be the optimal encapsulation for artificial seed production because of its sensible thickness, weak spinnability of solution, low toxicity of micro-organism, low expense, bio-suitability characteristics and, fast gellation. This material improves capsule structure and bead rigidity, supplying better protection to covered explants against mechanical hurt $[6,8]$. The major principle for alginate encapsulation formation depends on the exchange ions between $\mathrm{Na}+$ in sodium alginate with $\mathrm{Ca}+$ in $\mathrm{CaCl}_{2} \cdot 2 \mathrm{H}_{2} \mathrm{O}$, which happens when sodium alginate droplets involving the artificial embryos or any other plant propagule is dropped into the $\mathrm{Ca}_{2} \cdot 2 \mathrm{H}_{2} \mathrm{O}$ solution, producing stable explant beads. The solidity and rigidity of the capsule (explant beads) depends upon the two gelling agents' (sodium alginate and $\mathrm{CaCl}_{2} \cdot 2 \mathrm{H}_{2} \mathrm{O}$ ) concentrations and mixing duration. Nutrients should also be added to the artificial endosperm in order to maintain germplasm survival [49], obtain faster explant growth [79], and supply the energy required for germination, which is normally provided by endosperm or gametophyte tissue in true seeds [80]. On other hand, the addition of growth regulators and nutrients to the capsule is an essential factor to a successful artificial seed production technique, increasing the competence of germination and viability of these seeds. These materials are considered as artificial endosperm and they also play an important role in the artificial seed storage capability [8]. However, there are many other materials such as pesticide, antibiotics, and fungicide, which have positive effects in the capsule features.

\section{Artificial Endosperm Structure and Their Effects in the Artificial Seed Characters}

The endosperm of artificial seeds could be similar to the endosperm of seeds, but can also be manipulated so as to control growth and reduce the difficulties of the germination of somatic embryos [53,60,81]. While Saiprasad [8] mentioned that usually 3\% sodium with complexing solution 
containing $75 \mathrm{mM} \mathrm{Ca}_{2} \mathrm{Cl}_{2} \cdot 2 \mathrm{H}_{2} \mathrm{O}$ for half an hour mixing duration provides the optimal structure for artificial seed bead formation, Ara et al. [6] indicated that generally $2 \%$ sodium alginate gel upon complexation with $100 \mathrm{mM} \mathrm{CaCl} \cdot 2 \mathrm{H} 2 \mathrm{O}$ is the best. However, not just the concentrations of gel agents, but also the mixing duration has important effects on the rigidity and hardness of artificial seeds, which in turn greatly affect their characteristics (such as germination, storage ability). Daud et al. [7] mentioned that the germination level of African violet species was $72-80 \%$ when $30 \mathrm{~min}$ sodium alginate exposure duration was applied, compared to $52 \%$ when 10 min exposure duration was applied. However, these factors depend on others such as plant species, explants type, and the aim of the study, such as for short storage, long storage, or to obtain high germination level. However, lots of studies working in different plant species have investigated the optimal capsule structure which provides the highest germination rate, best seed viability, and their effects in the artificial seed storage duration (Table 1).

The ultimate viability of the artificial seeds can be affected by the matrix material or simulated endosperm, as the matrix is responsible for the immediate surrounding of the plant materials. The temporal and quantitative supplement of growth regulators and nutrients along with an optimal physical environment can determine the quality of artificial seeds [82,83]. An artificial seed can also be used as a carrier for micro-organisms, nutrients, antibiotics, plant growth regulators, pesticides, and fungicides. Also, it provides not only the physical protection for embryos [84] but also the carbon source [49] and growth regulators to control and sustain growth through germination [85]. The endosperm of artificial seeds could be similar to the endosperm of seeds, but can also be manipulated so as to control growth and to reduce the difficulties of the germination of somatic embryos $[53,60,81]$.

Artificial endosperm has a great effect on the germination level. In this way, Ara et al. [48] mentioned that the percentage of encapsulated somatic embryos germination of Mangifera indica L. was higher than non-encapsulated somatic embryos of the similar size in the same medium. Many studies also have demonstrated the important role of artificial endosperm structure (capsulation structure) in the artificial seed storage capability (Table 1). Lakshmana Rao and Singh [86] indicated that the reduction in germination level of encapsulated somatic embryos of hybrid Solanium-melongenal was much lower than in naked somatic embryos after 60-days storage at $4{ }^{\circ} \mathrm{C}$. Furthermore, while the encapsulated pieces of embryos mass got back their basic proliferative ability after 60 -days storage, naked fragments failed in that aspect [46].

\section{Artificial Seeds Storage Ability}

Several studies have investigated the artificial seed's storage capability (Table 1). Rai et al. [87] reported that a high concentration of sucrose or ABA could be useful for short-term conservation of guava (Psidium guajava L.) because of their temporary inhibition in encapsulated somatic embryos germination (Table 1). Working with Rauvolvia serpentine and applying three different temperature degrees $\left(20^{\circ} \mathrm{C}, 12{ }^{\circ} \mathrm{C}\right.$, and $\left.4{ }^{\circ} \mathrm{C}\right)$, Ray and Bhattacharya [88] indicated that $4{ }^{\circ} \mathrm{C}$, where storage achieved up to 14 weeks with high regrowth percentage (Table 1), was the optimal temperature for short storage duration. However, while short artificial seed storage can be obtained by applying several procedures—such as using suitable temperature (usually $4{ }^{\circ} \mathrm{C}$ ), suitable capsulation materials, and optimal storage conditions (reduced heat, light, oxygen, etc.) (Figure 3)—long storage can be achieved using dehydration and/or cryopreservation techniques (Figure 3).

Fabre and Dereuddre [89], working on Solanum shoot tips and aiming to increase the tolerance of plant tissue to dehydration-cryopreservation storage conditions, reported a full protocol for encapsulation-dehydration and storage. This protocol consists of three procedures: (a) preculturing encapsulated explants in a medium containing high concentrations of sucrose; (b) drying the encapsulated micro-organism; and (c) direct plunging into liquid nitrogen. Unfortunately, few research projects have investigated in depth the artificial seed preservation (dehydration-cryopreservation), and this technique still needs more studies in view of the great value of artificial seeds as an easy 
and cost-efficient method of germplasm preservation [14]. Furthermore, artificial seed conservation facilitates the exchange and distribution of trait plant germplasm, decreasing the requirement for transferring and subculturing out of season [24,62].

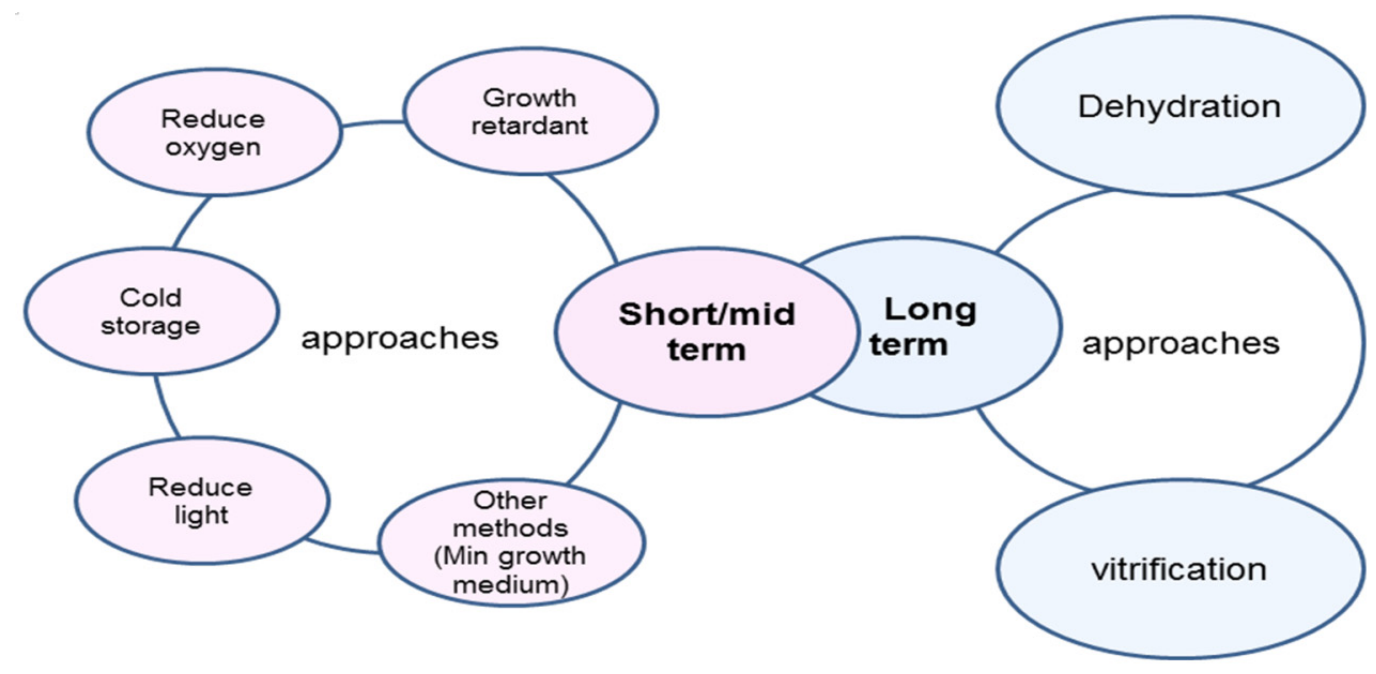

Figure 3. Artificial seed storage approaches (modified from [41]). 
Table 1. The recent applications of artificial seeds on different types of plants.

\begin{tabular}{|c|c|c|c|c|c|c|c|c|}
\hline Reference & $\begin{array}{l}\text { Species and } \\
\text { Explant Used }\end{array}$ & $\begin{array}{l}\text { Pre-Encapsulation } \\
\text { Culture }\end{array}$ & Capsule Structure & Additional Materials & $\begin{array}{l}\text { Storage } \\
\text { Conditions }\end{array}$ & $\begin{array}{l}\text { Post Storage } \\
\text { Treatment or Culture }\end{array}$ & $\begin{array}{l}\text { Storage } \\
\text { Duration }\end{array}$ & Experiment Assessment \\
\hline [90] & $\begin{array}{l}\text { Apical segments of } \\
\text { Turkey oak } \\
\text { (Quercus cerris L.) }\end{array}$ & $\begin{array}{l}\text { Modified GD } \\
\text { medium }[91] 0.88 \\
\text { BAP + 7.5 g. } \mathrm{L}^{-1} \text { agar }\end{array}$ & $\begin{array}{l}4 \%(w / v) \mathrm{SA} \\
\text { immersed in } \\
1.4 \%(w / v) \mathrm{CaCl}_{2} \text { for } \\
10 \mathrm{~min}\end{array}$ & $\begin{array}{l}\text { GD modified medium + } \\
0.88 \mathrm{mM} \text { BAP }\end{array}$ & $4^{\circ} \mathrm{C}$ & - & 6 weeks & $\begin{array}{l}85 \% \text { regeneration and } 95 \% \\
\text { viability }\end{array}$ \\
\hline [92] & $\begin{array}{l}\text { Shoot tips of azalea } \\
\text { (Rhododendorn simsii } \\
\text { Planch.) }\end{array}$ & $\begin{array}{l}\text { Modified (WPM) } \\
\text { medium }+(0.3,0.45 \\
0.6 \mathrm{M}) \text { sucrose }(24) \mathrm{h}\end{array}$ & $\begin{array}{l}\text { drops SA immersed } \\
\text { in } \mathrm{CaCl}_{2} \text { for } 15 \mathrm{~min}\end{array}$ & $\begin{array}{l}1.62 \mathrm{M} \text { glycerol + } 0.32 \mathrm{M} \\
\text { sucrose (cryoprotectants) }\end{array}$ & $\begin{array}{l}\text { Dehydration to } \\
\text { WC }(38.6) \%+ \\
\text { transfer to LN }\end{array}$ & $\begin{array}{l}\text { Detoxification in (1) M } \\
\text { sucrose for (2) } \mathrm{h}\end{array}$ & $24 \mathrm{~h}$ & $40 \%$ survived after thawing \\
\hline [24] & $\begin{array}{l}\text { Nodal segments of } \\
\text { promegranate } \\
\text { (Punica granatum L.) }\end{array}$ & - & $\begin{array}{l}3 \% \mathrm{Sa}+100 \mathrm{mM} \\
\mathrm{CaCl}_{2} \text { for } 30 \mathrm{~min}\end{array}$ & $\begin{array}{l}\text { MS medium + } 4.44 \mathrm{mM} \\
(\mathrm{BA})+0.54 \mathrm{mM}(\mathrm{NAA})\end{array}$ & $4{ }^{\circ} \mathrm{C}$ & $\begin{array}{l}\text { (MS) medium }+4.44 \mathrm{mM} \\
(\mathrm{BA})+0.54 \mathrm{mM}(\mathrm{NAA})\end{array}$ & 30 days & $\begin{array}{l}\text { The nodals were capable of } \\
\text { sprouting. }\end{array}$ \\
\hline [93] & $\begin{array}{l}\text { Nodal segments of } \\
\text { Rauvolfia tetraphylla } \mathrm{L} \text {. }\end{array}$ & $\begin{array}{l}\text { MS medium + } 10 \mathrm{mM} \\
\mathrm{BA}+0.5 \mathrm{mM} \text { NAA }+ \\
3 \%(w / v) \text { sucrose }+ \\
0.8 \%(w / v) \text { agar }\end{array}$ & $\begin{array}{l}3 \% \mathrm{SA}+100 \mathrm{mM} \text { for } \\
30 \mathrm{~min}\end{array}$ & MS medium & $4^{\circ} \mathrm{C}$ & $\begin{array}{l}\text { MS medium }+10 \mathrm{mM} \mathrm{BA}+ \\
0.5 \mathrm{NAA}+3 \% \text { sucrose }+ \\
0.8 \% \text { agar }\end{array}$ & 4 weeks & Shoot proliferation $86.7 \%$ \\
\hline [94] & $\begin{array}{l}\text { Shoot buds were } \\
\text { derived from lam } \\
\text { (Progonatherum } \\
\text { paniceum) calli }\end{array}$ & $\begin{array}{l}\text { MS medium } \\
\text { supplemented with } \\
2.0 \mathrm{mg} \cdot \mathrm{L}^{-1} \mathrm{BAP} \text { and } \\
0.2 \mathrm{mg} \cdot \mathrm{L}^{-1} \mathrm{NAA} \text {. }\end{array}$ & $\begin{array}{l}3.0 \% \mathrm{SA}+2 \% \mathrm{CaCl}_{2} \\
\text { for } 20 \mathrm{~min}\end{array}$ & $\begin{array}{l}1 \% \text { activate carbon }(w / v) \\
+0.3 \% \text { bavistin }(w / v)+ \\
\text { MS medium containing } \\
3 \% \text { sucrose }\end{array}$ & - & $\begin{array}{l}\text { substrata containing } \\
8 \mathrm{~g} \cdot \mathrm{L}^{-1} \text { agar with } \\
\text { half-strength MS medium } \\
\text { and } 2 \% \text { sucrose }\end{array}$ & - & $61.58 \%$ conversion rate \\
\hline [95] & $\begin{array}{l}\text { Node explants of } \\
\text { mugwort } \\
\text { (Artemisia vulgaris) }\end{array}$ & $\begin{array}{l}\text { Nodal segments } \\
\text { were excised } \\
\text { from poliferating } \\
\text { microshoots }\end{array}$ & $\begin{array}{l}2 \% \mathrm{SA}+50 \mathrm{mM} \\
\mathrm{CaCl}_{2} \text { for } 15-25 \mathrm{~min}\end{array}$ & - & $5^{\circ} \mathrm{C}$ & MS $+3 \%(w / v)$ sucrose & 60 weeks & $\begin{array}{l}85 \% \text { of encapsulated nodal } \\
\text { segments survived on } \\
\text { poliferation mendium }\end{array}$ \\
\hline [88] & $\begin{array}{l}\text { Shoot tips of } \\
\text { Rauvolfia serpentina }\end{array}$ & $\begin{array}{l}\text { MS medium }+3 \% \\
\text { sucrose } 0.8 \% \text { agar }\end{array}$ & $\begin{array}{l}3 \% \mathrm{SA}+100 \mathrm{mM} \\
\mathrm{CaCl}_{2} \text { for } 45 \mathrm{~min}\end{array}$ & $\begin{array}{l}\text { Encapsulated shoot tips } \\
\text { kept in vessels containing } \\
\text { MS }+3 \% \text { sucrose during } \\
\text { storage period }\end{array}$ & $4{ }^{\circ} \mathrm{C}$ & MS $+3 \%$ scrose & 14 weeks & $\begin{array}{l}(68.5-100 \%) \text { regrowth rate } \\
\text { during storage period } \\
\text { (several tests in the normal } \\
\text { culture conditions) }\end{array}$ \\
\hline [87] & $\begin{array}{l}\text { Somatic embryos of } \\
\text { guava (Psidium } \\
\text { guajava L.) }\end{array}$ & - & $\begin{array}{l}2 \% \mathrm{SA}+100 \mathrm{mM} \\
\mathrm{CaCl}_{2} \text { for } 20-30 \mathrm{~min}\end{array}$ & $\begin{array}{l}\text { Encapsulated somatic } \\
\text { embryos }+\mathrm{MS}+9 \% \\
\text { sucrose or }+\mathrm{MS}+ \\
1 \mathrm{mg} \cdot \mathrm{L}^{-1} \mathrm{ABA}\end{array}$ & $25 \pm 2^{\circ}$ & MS $+3 \%$ sucrose & 60 days & $\begin{array}{l}28.8 \% \text { germination level and } \\
37.5 \% \text { germination level } \\
\text { For (sucrose and } \\
\text { ABA respectively) }\end{array}$ \\
\hline [35] & $\begin{array}{l}\text { Somatic embryos } \\
\text { from mature seeds of } \\
\text { rauli-beech } \\
\text { (Nothofagus alpine) }\end{array}$ & - & $\begin{array}{l}3 \% \mathrm{SA}+5.5 \mathrm{~g} \cdot \mathrm{L}^{-1} \\
\mathrm{CaCl}_{2} \text { for } 30 \mathrm{~min}\end{array}$ & $\begin{array}{l}\mathrm{MS}+0.5 \mathrm{mg} \cdot \mathrm{L}^{-1} \mathrm{IAA}+ \\
0.5 \mathrm{mg} \cdot \mathrm{L}^{-1} \mathrm{NAA}+ \\
2 \mathrm{mg} \cdot \mathrm{L}^{-1} \mathrm{BAP}+ \\
30 \mathrm{sucrose}\end{array}$ & - & $\begin{array}{l}\text { culture MS }+30 \mathrm{~g} \cdot \mathrm{L}^{-1} \\
\text { sucrose }+7 \mathrm{~g} \cdot \mathrm{L}^{-1} \text { agar }\end{array}$ & - & $\begin{array}{l}\text { The germination rate was } \\
45 \% \text { after } 4 \text { weeks }\end{array}$ \\
\hline [38] & $\begin{array}{l}\text { Axillary buds of } \\
\text { Cannabis sativa } \mathrm{L} \text {. }\end{array}$ & $\begin{array}{l}\text { MS medium }+ \\
3 \%(w / v) \text { sucrose }+ \\
0.8 \% \text { agar }+ \\
0.5 \mathrm{mM}(\mathrm{TDZ})\end{array}$ & $\begin{array}{l}5 \% \mathrm{SA}+\mathrm{CaCl}_{2} \text { for } \\
30 \mathrm{~min}\end{array}$ & $\begin{array}{l}\text { MS + } 0.5 \mathrm{mM}(\mathrm{TDZ})+ \\
2.5 \mathrm{mM}(\mathrm{IBA}) . \mathrm{A}+ \\
\text { fungicide + } 5 \%(\mathrm{PPM})\end{array}$ & - & $\begin{array}{l}\text { MS medium + } 0.5 \mathrm{TDZ}+ \\
0.075 \% \text { PPM }\end{array}$ & - & $\begin{array}{l}100 \% \text { artificial seed } \\
\text { conversion rate }\end{array}$ \\
\hline
\end{tabular}




\section{Limitation of Artificial Seeds}

The main requirement for an efficient artificial seed production protocol is the large-scale production of highly valuable micopropagules suitable for encapsulation in sodium alginate matrix, at low cost per culture unit. However, although the design of such systems was achieved in some plant species, such as cauliflower (Brassica oleraceae var. botrytis L.) [11,76,96-98], the micropropagation system is still one of the major limitations of the development of artificial seed technology.

Although the use of somatic embryos has been widely reported for artificial seed production in various plant species [31], there are some major challenges that need to be solved to improve the efficiency of these protocols. The advantages of artificial seed technology are encountered by challenges such as limitations in storage caused by lack of dormancy, synchronic deficiency in somatic embryo development, improper maturation, low levels of conversion into plantlets, limitation in production of viable mature somatic embryos, [99] and the reduction of viability and plant recovery when the artificial seeds are stored at low temperature [100].

In the species that are recalcitrant to somatic embryogenesis, the possibility of using non-embryogenic propagules for artificial seed production was investigated in different plant species and reported to be a promising pathway as a propagation method. However, this pathway encountered some complications such as the difficulties of achieving one rooting step for non-embryogenic artificial seeds [101]. The difficulties of sowing artificial seeds directly in soil or in commercial substrates such as compost, vermiculite, etc., under non-sterile conditions are considered to be one of the main limitations of the practical use of this technique [76,102].

\section{Conclusions}

Artificial seeds were produced successfully from encapsulated plant propagules in different plant species. Procedures were optimized and proper plantlets were obtained. This technique has great advantages such as: a cost-effective delivery system, minimization of the cost of plantlets, simple methodology with high potential for mass production, a promising technique for the direct use of artificial seedlings in vivo, and a high storage capacity. The advances of this technique depend on the plant species in the first step.

However, despite the advantages of artificial seeds, further research is required in order to improve root formation of non-embryogenic artificial seeds. More investigations are needed to improve the capacity of artificial seed cultivation in commercial substrates and under non-sterilized conditions. This could be improved by the use of suitable types and concentrations of anti-diseases and antibiotics, and further detailed research is needed for improvement in the artificial seed cryopreservation capacity in some plant species.

Author Contributions: For research articles with several authors, a short paragraph specifying their individual contributions must be provided. Hail Z. Rihan wrote the entail version of the article. Mohammed E. El-Mahrouk and Fakhriya Kareem updated the article and helped to include most recent achievements in the field of artificial seed production. Michael P. Fuller edited and supervised the work throughout the writing and preparation process.

Conflicts of Interest: The authors declare no conflict of interest.

\section{Abbreviations}

$\begin{array}{ll}\text { SA } & \text { sodium alginate } \\ \text { WPM } & \text { woody plant medium } \\ \text { BAP } & \mathrm{N}^{6} \text {-benzylaminopurine } \\ \text { BA } & \text { 6-Benzylaminopurine } \\ \text { MS } & \text { Murashige and Skoog medium } \\ \text { NAA } & \text { naphathaleneacetic acid } \\ \text { GD } & \text { Gresshoff and Doy medium } \\ \text { IAA } & \text { indolacetic acid } \\ \text { LN } & \text { liquid nitrogen }\end{array}$




\section{References}

1. Murashige, T. Plant cell and organ cultures as horticultural practices. In Proceedings of the Symposium on Tissue Culture for Horticultural Purposes, Ghent, Belgium, 6-9 September 1977.

2. Gray, D.J.; Purohit, A.; Triglano, R.N. Somatic embryogenesis and development of synthetic seed technology. Crit. Rev. Plant Sci. 1991, 10, 33-61. [CrossRef]

3. Redenbaugh, K.; Paasch, B.D.; Nichol, J.W.; Kossler, M.E.; Viss, P.R.; Walker, K.A. Somatic seeds-encapsulation of asexual plant embryos. Nat. Biotechnol. 1986, 4, 797-801. [CrossRef]

4. Redenbaugh, K.; Fujii, J.A.; Slade, D. Encapsulated plant embryos. In Advances in Biotechnological Processes; Mizrahi, A., Ed.; Alan R. Liss Inc.: New York, NY, USA, 1988; pp. 225-248.

5. Bapat, V.A.; Mhatre, M.; Rao, P.S. Propagation of Morus indica L. (Mulberry) by encapsulated shoot buds. Plant Cell Rep. 1987, 6, 393-395. [CrossRef] [PubMed]

6. Ara, H.; Jaiswal, U.; Jaiswal, V. Synthetic seed: Prospects and limitation. Curr. Sci. 2000, 78, 1438-1444.

7. Daud, M.; Taha, M.Z.; Hasbullah, A.Z. Artificial seed production from encapsulated micro shoots of Sainpaulia ionantha Wendl. (African Violet). J. Appl. Sci. 2008, 8, 4662-4667.

8. Saiprasad, G. Artificial seeds and their applications. Resonance 2001, 6, 39-47. [CrossRef]

9. Onishi, N.; Sakamoto, Y.; Hirosawa, T. Synthetic seeds as an applicationof mass-production of somatic embryos. Plant Cell Tissue Organ Cult. 1994, 39, 137-145. [CrossRef]

10. Sharma, S.; Shahzad, A. Encapsulation technology for short-term storage and conservation of a woody climber, Decalepis hamiltonii Wight and Arn. Plant Cell Tissue Organ Cult. 2012, 111, 191-198. [CrossRef]

11. Rihan, H.Z.; Al-Issawi, M.; Burchett, S.; Fuller, M.P. Encapsulation of cauliflower (Brassica oleracea var botrytis) microshoots as artificial seeds and their conversion and growth in commercial substrates. Plant Cell Tissue Organ Cult. 2011, 107, 243-250. [CrossRef]

12. Ahmad, N.; Anis, M. Direct plant regeneration from encapsulated nodal segments of Vitex negundo. Biol. Plant. 2010, 54, 748-752. [CrossRef]

13. Rai, M.K.; Jaiswal, V.S.; Jaiswal, U. Encapsulation of shoot tips of guava (Psidium guajava L.) for short-term storage and germplasm exchange. Sci. Hortic. 2008, 118, 33-38. [CrossRef]

14. Danso, K.E.; Ford-Lloyd, B.V. Encapsulation of nodal cuttings and shoot tips for storage and exchange of cassava germplasm. Plant Cell Rep. 2003, 21, 718-725. [PubMed]

15. Bapat, V.A.; Rao, P.S. Sandalwood plantlets from synthetic seeds. Plant Cell Rep. 1988, 7, 434-436. [PubMed]

16. Mathur, J.; Ahuja, P.S.; Lal, N.; Mathur, A.K. Propagation of Valeriana wallichii DC. using encapsulated apical and axial shoot buds. Plant Sci. 1989, 60, 111-116. [CrossRef]

17. Ganapathi, T.R.; Suprasanna, P.; Bapat, V.A.; Rao, P.S. Propagation of banana through encapsulated shoot tips. Plant Cell Rep. 1992, 11, 571-575. [CrossRef] [PubMed]

18. Corrie, S.; Tandon, P. Propagation of Cymbidium giganteum wall through high frequency conversion of encapsulated protocorms under in vivo and in vitro conditions. Indian J. Exp. Biol. 1993, 31, 61-64.

19. Sharma, T.R.; Singh, B.M.; Chauhan, R.S. Production of disease free encapsulated buds of Zingiber officinale Rosc. Plant Cell Rep. 1994, 13, 300-302. [CrossRef] [PubMed]

20. Sarkar, D.; Naik, P.S. Synseeds in potato: An investigation using nutrient-encapsulated in vitro nodal segments. Sci. Hortic. 1998, 7, 179-184. [CrossRef]

21. Mandal, J.; Pattnaik, S.; Chand, P. Alginate encapsulation of axillary buds of Ocimum americanum L. (hoary basil), Basilicum L. (sweet basil), Gratissimum L. (shrubby basil), and Sanctum L. In Vitro Cell. Dev. Biol. Plant 2000, 36, 287-292. [CrossRef]

22. Nyende, A.B.; Schittenhelm, S.; Mix-Wagner, G.; Greef, J.M. Production, storability, and regeneration of shoot tips of potato (Solanum tuberosum L.) encapsulated in calcuim alginate hollow beads. In Vitro Cell. Dev. Biol. Plant 2003, 39, 540-544. [CrossRef]

23. Chand, S.; Singh, A.K. Plant regeneration from encapsulated nodal segments of Dalbergia sissoo Roxb, a timber-yielding leguminous tree species. J. Plant Physiol. 2004, 161, 237-243. [CrossRef] [PubMed]

24. Naik, S.K.; Chand, P.K. Nutrient-alginate encapsulation of in vitro nodal segments of pomegranate (Punica granatum L.) for germplasm distribution and exchange. Sci. Hortic. 2006, 108, 247-252. [CrossRef]

25. Singh, A.K.; Varshney, R.; Sharma, M.; Agarwal, S.S.; Bansal, K.C. Regeneration of plants from alginate-encapsulated shoot tips of Withania somnifera (L.) Dunal, a medicinally important plant species. J. Plant Physiol. 2006, 163, 220-223. [CrossRef] [PubMed] 
26. Faisal, M.; Anis, M. Regeneration of plants from alginate-encapsulated shoots of Tylophora indica (Burm. f.) Merrill, an endangered medicinal. J. Hortic. Sci. Biotechnol. 2007, 82, 351-354. [CrossRef]

27. Micheli, M.; Hafiz, I.A.; Standardi, A. Encapsulation of in vitro-derived explants of olive (Olea europaea L. cv. Moraiolo): II. Effects of storage on capsule and derived shoots performance. Sci. Hortic. 2007, 113, $286-292$. [CrossRef]

28. Rai, M.K.; Jaiswa, V.S. Alginate-encapsulation of nodal segments of guava (Psidium guajava L.) for germplasm exchange and distribution. J. Hortic. Sci. Biotechnol. 2008, 83, 569-573. [CrossRef]

29. Rai, M.K.; Asthana, P.; Singh, S.K.; Jaiswal, V.S.; Jaiswal, U. The encapsulation technology in fruit plants-A review. Biotechnol. Adv. 2009, 27, 671-679. [CrossRef] [PubMed]

30. Singh, S.K.; Rai, M.K.; Asthana, P.; Pandey, S.; Jaiswal, V.S.; Jaiswal, U. Plant regeneration from alginate-encapsulated shoot tips of Spilanthes acmella L. Murr., a medicinally important and herbal pesticidal plant species. Acta Physiol. Plant. 2009, 31, 649-653. [CrossRef]

31. Sharma, S.; Shahzad, A.; da Silva, J.A.T. Synseed technology-A complete synthesis. Biotechnol. Adv. 2013, 31, 186-207. [CrossRef] [PubMed]

32. Pattnaik, S.K.; Sahoo, Y.; Chand, P.K. Efficient plant retrieval from alginate-encapsulated vegetative buds of mature mulberry trees. Sci. Hortic. 1995, 61, 227-239. [CrossRef]

33. Banerjee, S.; Singh, S.; Pandey, H.; Pandey, P.; ur Rahman, L. Conservation and storage of Curcuma amada Roxb. synseeds on Luffa sponge matrix and RAPD analysis of the converted plantlets. Ind. Crop. Prod. 2012, 36, 383-388. [CrossRef]

34. Redenbaugh, K.; Slade, D.; Viss, P.; Fujii, J.A. Encapsulation of somatic embryos in synthetic seed coats. HortScience 1987, 22, 803-809.

35. Cartes, P.; Castellanos, H.; Ríos, D.; Sáez, K.; Spierccolli, S.; Sánchez, M. Encapsulated somatic embryos and zygotic embryos for obtaining artificial seeds of rauli-beech (Nothofagus alpina (Poepp. \& Endl.) oerst.). Chil. J. Agric. Res. 2009, 69, 112-118.

36. Standardi, A.; Micheli, M. Encapsulation of in vitro-derived explants: An innovative tool for nurseries. Methods Mol. Biol. 2013, 11013, 397-418. [PubMed]

37. Nyende, A.B.; Schittenhelm, S.; Mix-Wagner, G.; Greef, J.M. Yield and canopy development of field grown potato plants derived from synthetic seeds. Eur. J. Agron. 2005, 22, 175-184. [CrossRef]

38. Lata, H.; Chandra, S.; Khan, I.A.; ElSohly, M.A. Propagation through alginate encapsulation of axillary buds of Cannabis sativa L.-An important medicinal plant. Physiol. Mol. Biol. Plants 2009, 15, 79-86. [CrossRef] [PubMed]

39. Pennycooke, J.C.; Towill, L.E. Medium alterations improve regrowth of sweet potato (Ipomoea batatas (L.) Lam.) shoot tips cryopreserved by vitrification and encapsulation-dehydration. Cryoletters 2001, 22, 381-389. [PubMed]

40. Wang, Q.; Batuman, Ö.; Li, P.; Bar-Joseph, M.; Gafny, R. A simple and efficient cryopreservation of in vitro-grown shoot tips of 'Troyer' citrange [Poncirus trifoliata (L.) Raf. $\times$ Citrus sinensis (L.) Osbeck.] by encapsulation-vitrification. Euphytica 2002, 128, 135-142. [CrossRef]

41. Mohamed, M. Application of Synthetic Seeds-Present and the Future. Available online: http://www.scribd. com/doc/22585470/Application-of-Synthetic-Seeds-Present-and-the-Future (accessed on 28 December 2009).

42. Leroy, X.J.; Leon, K.; Charles, G.; Branchard, M. Cauliflower somatic embryogenesis and analysis of regenerant stability by ISSRs. Plant Cell Rep. 2000, 19, 1102-1107. [CrossRef]

43. Deng, W. A novel method for induction of plant regeneration via somatic embryogenesis. Plant Sci. 2009, 177, 43-48. [CrossRef]

44. Kitto, S.L.; Janick, J. Polyox as an artificial seed coat for a sexual embryos. HortScience 1982, 17, 488.

45. Gupta, P.K.; Durzan, D.J. Somatic embryos from protoplasts of Loblolly-pine proembryonal cells. Nat. Biotechnol. 1987, 5, 710-712. [CrossRef]

46. Onay, A.; Jeffree, C.E.; Yeoman, M.M. Plant regeneration from encapsulated embryoids and an embryogenic mass of pistachio, Pistacia vera L. Plant Cell Rep. 1996, 15, 723-726. [CrossRef] [PubMed]

47. Ghosh, B.; Sen, S. Plant-regeneration from alginate encapsulated somatic embryos of Asparaguscooperi-baker. Plant Cell Rep. 1994, 13, 381-385. [CrossRef] [PubMed]

48. Ara, H.; Jaiswal, U.; Jaiswal, V.S. Germination and plantlet regeneration from encapsulated somatic embryos of mango (Mangifera indica L.). Plant Cell Rep. 1999, 19, 166-170. [CrossRef] 
49. Antonietta, G.M.; Emanuele, P.; Alvaro, S. Effects ofencapsulation on Citrus reticulata Blanco somatic embryo conversion. Plant Cell Tissue Organ Cult. 1999, 55, 235-237. [CrossRef]

50. Sunilkumar, K.K.; Sudhakara, K.; Vijaykumar, N.K. An attempt to improve storage life of Hopea parviflora seeds through synthetic seed production. Seed Res. 2000, 28, 126-130.

51. Ipekei, Z.; Gozukirmizi, N. Direct somatic embryogenesis and synthetic seed production from Paulownia elongata. Plant Cell Rep. 2003, 22, 16-24. [CrossRef] [PubMed]

52. Nieves, N.; Zambrano, Y.; Tapia, R.; Cid, M.; Pina, D.; Castillo, R. Field performance of artificial seed derived sugarcane plants. Plant Cell Tissue Organ Cult. 2003, 75, 279-282. [CrossRef]

53. Kumar, M.B.A.; Vakeswaran, V.; Krishnasamy, V. Enhancement of synthetic seed conversion to seedlings in hybrid rice. Plant Cell Tissue Organ Cult. 2005, 81, 97-100. [CrossRef]

54. Chithra, M.; Martin, K.P.; Sunandakumari, C.; Madhusoodanan, P.V. Somatic embryogenesis, encapsulation, and plant regeneration of Rotula aquatica lour, a rare rhoeophytic woody medicinal plant. In Vitro Cell. Dev. Biol. Plant 2005, 41, 28-31. [CrossRef]

55. Aquea, F.; Poupin, M.J.; Matus, J.T.; Gebauer, M.; Medina, C.; Arce-Johnson, P. Synthetic seed production from somatic embryos of Pinus radiata. Biotechnol. Lett. 2008, 30, 1847-1852. [CrossRef] [PubMed]

56. Maqsood, M.; Mujib, A.; Siddiqui, Z.H. Synthetic seed development and conversion to plantlet in Catharanthus roseus (L.) G. Don. Biotechnology 2012, 11, 37-43.

57. Attree, S.M.; Pomeroy, M.K.; Fowke, L.C. Production of vigoous, dessication tolerant white spruce (Picea-glauca (moench) voss) synthetic seeds in a bioreactor. Plant Cell Rep. 1994, 13, 601-606. [CrossRef] [PubMed]

58. Lulsdorf, M.M.; Tautorus, T.E.; Kikcio, S.I.; Bethune, T.D.; Dunstan, D.I. Germenation of encapsulated embryos of interior spruce (Picea-glauca-engelmanni complex) and black spruce (Picea-mariqana Mill). Plant Cell Rep. 1993, 12, 385-389. [PubMed]

59. Ganapathi, T.R.; Srinivas, L.; Suprasanna, P.; Bapat, V.A. Regeneration of plants from alginate-encapsulated somatic embryos of banana cv. Rasthali (Musa SPP. AAB Group). In Vitro Cell. Dev. Biol. Plant 2001, 37, 178-181. [CrossRef]

60. Malabadi, R.B.; van Staden, J. Storability and germination of sodium alginate encapsulated somatic embryos derived from the vegetative shoot apices of mature Pinus patula trees. Plant Cell Tissue Organ Cult. 2005, 82, 259-265. [CrossRef]

61. Manjkhola, S.; Dhar, U.; Joshi, M. Organogenesis, embryogenesis, and synthetic seed production in Arnebia euchroma-A critically endangered medicinal plant of the Himalaya. In Vitro Cell. Dev. Biol. Plant 2005, 41, 244-248. [CrossRef]

62. West, T.P.; Ravindra, M.B.; Preece, J.E. Encapsulation, cold storage, and growth of Hibiscus moscheutos nodal segments. Plant Cell Tissue Organ Cult. 2006, 87, 223-231. [CrossRef]

63. Gomez, R. Embriogénesis somática. In Propagación y Mejora Genética de Plantas por Biotecnología; Pérez, J.N., Ed.; Instituto de Biotecnología de las Plantas: Santa Clara, Cuba, 1998; pp. 57-79.

64. Rodríguez, N.N.; Lorenzo, F.; Blanco, J.M.A.; González, O.; Tapia, T. Composicion de un endospermo artificial para embriones de mandarina 'Cleopatra' (Citrus reshni Hort es Tan). Rev. Fac. Agron. 2001, 27, 11-15.

65. Nair, R.R.; Gupta, S.D. In vitro plant regeneration from encapsulated somatic embryos of black pepper (Piper nigrum L.). J. Plant Sci. 2007, 2, 283-292.

66. Tapia, R.; Castillo, R.; Nieves, N.; Blanco, M.A.; González, J.; Sánchez, M.; Rodríguez, Y. Inducción, Maduración Y Encapsulación De Embriones Somáticos De Caña De Azucar (Saccharum sp.) var CP 5243. Biotecnol. Apl. 1999, 16, 20-23.

67. Castellanos, H.; Sánchez-Olate, M.; Ríos, Y.D. Embriogénesis somática recurrente en raulí (Nothofagus alpina (Poepp. et Endl.) Oerst.). In Segundo Congreso Chileno de Ciencias Forestales, Valdivia, Chile. 10-12 de Noviembre; Universidad Austral de Chile: Valdivia, Chile, 2004; p. 36.

68. Bapat, V.A.; Mhatre, M. Bioencapsulation of Somatic Embryos in Woody Plants. In Protocol for Somatic Embryogenesis in Woody Plants; Springer: Dordrecht, The Netherlands, 2005; pp. 539-552.

69. Sundararaj, S.G.; Agrawal, A.; Tyagi, R.K. Encapsulation for in vitro short-term storage and exchange of ginger (Zingiber officinale Rosc.) germplasm. Sci. Hortic. 2010, 125, 761-766. [CrossRef]

70. Pond, S.; Cameron, S. Tissue Culture $\backslash$ Artificial Seed. In Encyclopedia of Applied Plant Sciences; Thomas, B., Ed.; Elsevier: Oxford, UK, 2003; pp. 1379-1388. 
71. Redenbaugh, K. Synseeds: Applications of Synthetic Seeds to Crop Improvement; CRC Press: Boca Raton, FL, USA, 1993; pp. 38-46.

72. Latif, Z.; Nasir, I.A.; Riazuddin, S. Indigenous production of synthetic seeds in Daucus carota. Pak. J. Bot. 2007, 39, 849-855.

73. Bapat, V.A.; Rao, P.S. In vivo growth of encapsulated axillary buds of mulberry (Morus-indical L.). Plant Cell Tissue Organ Cult. 1990, 20, 69-70. [CrossRef]

74. Piccioni, E.; Standardi, A. Encapsulation of micropropagated buds of 6 woody species. Plant Cell Tissue Organ Cult. 1995, 42, 221-226. [CrossRef]

75. Capuano, G.; Piccioni, E.; Standardi, A. Effect of different treatments on the conversion of M.26 apple rootstock synthetic seeds obtained from encapsulated apical and axillary micropropagated buds. J. Hortic. Sci. Biotechnol. 1998, 73, 299-305. [CrossRef]

76. Rihan, H.Z.; Al-Issawi, M.; Al-Swedi, F.; Fuller, M.P. The effect of using PPM (plant preservative mixture) on the development of cauliflower microshoots and the quality of artificial seed produced. Sci. Hortic. 2012, 141, 47-52. [CrossRef]

77. Datta, K.B.; Kanjilal, B.; de Sarker, D. Artificial seed technology: Development of a protocol in Geodorum densiflorum (Lam) Schltr.-An endangered orchid. Curr. Sci. 1999, 76, 1142-1145.

78. Redenbaugh, K.; Nichol, J.; Kossler, M.E.; Paasch, B. Encapsulation of Somatic Embryos for Artificial Seed Production. In Vitro J. Tissue Cult. Assoc. 1984, 20, 256-257.

79. Redenbaugh, K.; Fujii, J.A.; Slade, D. Hydrated coating for synthetic seeds. In Synseeds: Application of the Synthetic Seeds to Crop Improvement; CRC Press: Boca Raton, FL, USA, 1993; pp. 305-327.

80. Ahuja, M.R. Micropropagation of woody plants. In Synthetic Seeds in Forest Trees; Gupta, P., Kreitinger, M., Eds.; Kluwer Academic Publisher: Dordrecht, The Netherlands, 1993; p. 107.

81. Castillo, B.; Smith, M.A.L.; Yadava, U.L. Plant regeneration from encapsulated somatic embryos of Carica papaya L. Plant Cell Rep. 1998, 17, 172-176. [CrossRef]

82. Senaratna, T. Artificial seeds. Biotechnol. Adv. 1992, 10, 379-392. [CrossRef]

83. Khor, E.; Loh, C. Artificial seeds. In Applications of Cell Immobilization Biotechnology; Nedovic, V., Willaert, R., Eds.; Springer: Berlin/Heidelberg, Germany, 2005; pp. 527-537.

84. Gray, D.J. Synthetic seed for clonal production of crop plants. In Recent Advances in the Development and Germination of Seeds; Springer: Boston, MA, USA, 1989.

85. Nieves, N.; Lorenzo, J.C.; Blanco, M.A. Artificial endosperm of Cleopatra tangerine zygotic embryos: A model for somatic embryo encapsulation. Plant Cell Tissue Organ Cult. 1998, 54, 77-83. [CrossRef]

86. Lakshmana Rao, P.V.; Singh, B. Plantlet regeneration from encapsulated somatic embryos of hybrid Solanum melongena L. Plant Cell Rep. 1991, 10, 7-11. [CrossRef] [PubMed]

87. Rai, M.K.; Jaiswal, V.S.; Jaiswal, U. Effect of ABA and sucrose on germination of encapsulated somatic embryos of guava (Psidium guajava L.). Sci. Hortic. 2008, 117, 302-305. [CrossRef]

88. Ray, A.; Bhattacharya, S. Storage and plant regeneration from encapsulated shoot tips of Rauvolfia serpentine-An effective way of conservation and mass propagation. S. Afr. J. Bot. 2008, 74, 776-779. [CrossRef]

89. Fabre, J.; Dereuddre, J. Encapsulation dehydration-a new approach to cryopreservation of Solanium shoot-tips. Cryo-Letters 1990, 11, 413-426.

90. Tsvetkov, I.; Hausman, J.-F. In vitro regeneration from alginate-encapsulated microcuttings of Quercus sp. Sci. Hortic. 2005, 103, 503-507. [CrossRef]

91. Gresshof, P.M.; Doy, C.H. Development and differentiation of haploid lycopersicon-esculentum (tomato). Planta 1972, 107, 161-170. [CrossRef] [PubMed]

92. Verleysen, H.; van Bockstaele, E.; Debergh, P. An encapsulation-dehydration protocol for cryopreservation of the azalea cultivar 'Nordlicht' (Rhododendron simsii Planch.). Sci. Hortic. 2005, 106, 402-414. [CrossRef]

93. Faisal, M.; Ahmad, N.; Anis, M. In vitro plant regeneration from alginate-encapsulated microcuttings of Rauvolfia tetraphylla L. Am. Eurasian J. 2006, 1, 1-6.

94. Wang, W.G.; Wang, S.H.; Wu, X.A.; Jin, X.Y.; Chen, F. High frequency plantlet regeneration from callus and artificial seed production of rock plant Pogonatherum paniceum (Lam.) Hack. (Poaceae). Sci. Hortic. 2007, 113, 196-201. [CrossRef]

95. Sujatha, G.; Kumari, B.D.R. Micropropagation, encapsulation and growth of Artemisia vulgaris node explants for germplasm preservation. S. Afr. J. Bot. 2008, 74, 93-100. [CrossRef] 
96. Rihan, H.Z.; Al-Shamari, M.; Al-Swedi, F.; Burchett, S.; Fuller, M.P. The effect of sugar type, source and concentration on Brassica oleraceae var botrytis microproshoot production. Acta Hortic. 2013. under review.

97. Rihan, H.Z.; Al-Issawi, M.; Burchett, S.; Fuller, M.P. Artificial seed production from encapsulated microshoots of cauliflower (Brassica oleraceae var botrytis). Acta Hortic. 2012, 961, 419-425. [CrossRef]

98. Rihan, H.Z.; Shamari, M.; Fuller, M.P. The production of cauliflower microshoots using curd meristematic tissues and hypocotyl-derived callus. Acta Hortic. 2012, 961, 427-434. [CrossRef]

99. Reddy, M.C.; Murthy, K.S.R.; Pullaiah, T. Synthetic seeds: A review in agriculture and forestry. Afr. J. Biotechnol. 2012, 11, 14254-14275.

100. Makowczyńska, J.; Andrzejewska-Golec, E. Somatic seeds of Plantago asiatica L. Acta Soc. Bot. Pol. 2006, 75, 17-21.

101. Hung, C.; Trueman, S. Alginate encapsulation of shoot tips and nodal segments for short-term storage and distribution of the eucalypt Corymbia torelliana $\times$ C. citriodora. Acta Physiol. Plant 2012, 34, 117-128. [CrossRef]

102. Jung, S.J.; Yoon, E.S.; Jeong, J.H.; Choi, Y.E. Enhanced post-germinative growth of encapsulated somatic embryos of Siberian ginseng by carbohydrate addition to the encapsulation matrix. Plant Cell Rep. 2004, 23, 365-370. [CrossRef] [PubMed]

(C) 2017 by the authors. Licensee MDPI, Basel, Switzerland. This article is an open access article distributed under the terms and conditions of the Creative Commons Attribution (CC BY) license (http://creativecommons.org/licenses/by/4.0/). 